\title{
THE ANALYSIS OF MAIN MACROECONOMIC INDICATORS - A COMPARATIVE STUDY OF SERBIA AND THE SELECTED SEE COUNTRIES ${ }^{3}$
}

https://doi.org/10.18485/iipe_balkans_rssc.2020.ch20

\begin{abstract}
The analysis of the main macroeconomic indicators is important to show the overall state of the economy, predict its stability and enable investors, above all, to respond in a timely manner to sudden or unpredictable events. Accordingly, it can be said that the main macroeconomic indicators describe the state and efficiency of each national economy. The main objective of the paper is to present the current economic situation in the observed countries by looking at macroeconomic indicators: real GDP, unemployment rate, consumer and producer price, gross foreign direct investment, and total government debt. The subject of the paper is focused on comparative analysis of major macroeconomic indicators in the selected SEE countries (Bosnia and Herzegovina, Croatia, Montenegro, North Macedonia, Romania, Serbia and Slovenia). In order to get a clear picture of the current state of each of these economies, the secondary data for 2018 and the first two quarters of 2019 will be used in the analysis, all with the task of presenting any problems that may exist and their possible solutions. Comparing Serbia's position vis-à-vis other SEE countries, it can be concluded that it has transformed into a growing economy with low inflation, fiscal surpluses, declining public debt, lowering external imbalance, and a recovery in the labour market. It is expected that the growth trend will continue in the coming period, which will result in even better economic development and increased openness to new investments.

Keywords: GDP, unemployment rate, FDI, government debt.
\end{abstract}

\footnotetext{
${ }^{1}$ Research Associate, Institute of Economic Sciences, Belgrade, Serbia.

E-mail: darko.marjanovic@ien.bg.ac.rs.

${ }^{2}$ Senior Research Associate, Director of the Institute of Economic Sciences, Belgrade, Serbia. E-mail: jovan.zubovic@ien.bg.ac.rs.

${ }^{3}$ This paper is written as a part of research projects numbers III47009 (European integrations and social and economic changes in Serbian economy on the way to the EU) and OI179015 (Challenges and prospects of structural changes in Serbia: Strategic directions for economic development and harmonization with EU requirements), financed by the Ministry of Education, Science and Technological Development of the Republic of Serbia.
} 


\section{INTRODUCTION}

Macroeconomic policy is a set of government activities aimed at achieving the most important economic goals. Therefore, the basic goals of each country's macroeconomic policy are directed towards economic growth, high employment, as well as price and balance of payments stability. In addition, particular attention is paid to the budget deficit, which may influence the reduction of purchasing power to some extent and also the share of public debt related to gross domestic product. When it comes to macroeconomic policy, it is nowadays accepted that all activities are directed towards maintaining the overall balance and stimulating economic growth. For macroeconomic policy to be effective, it is necessary to ensure the sustainability of the factors that determine it, which primarily refers to the coherence of goals and instruments, as well as the reality of the goals themselves, coherence of macroeconomic policy measures, selection of the most effective measures, and timeliness in undertaking them. It is very important that economic policymakers, as the main subjects, adopt adequate measures and realize the set economic policy goals.

In the coming period, structural and institutional reforms should gradually strengthen the potential growth of countries that have not yet become EU members, helping them prepare for the accession process. Certainly, one of the main goals of these countries is to maintain macroeconomic and financial stability, which would contribute to better implementation of structural and institutional reform programs to achieve faster and more inclusive growth, job creation, and a better standard of living.

\section{LITERATURE REVIEW}

The relationship between economic growth and macroeconomic indicators has long been a popular issue of debate in the literature on economic development (Tas et al., 2013). Accurate and timely information on the current state of economic activity is an important requirement for the policymaking process (Sédillot and Pain, 2003).

The main goals of each country's macroeconomic policy today can be reduced to economic growth, high employment, price stability, and the balance of payments (Petrović et al., 2013). Josifidis (2010) presented three variants of macroeconomic goals in their research: (a) price stability, low unemployment, high and sustainable economic growth, (b) high output growth, steady output growth, low unemployment and low inflation, and 
(c) high level and high output rate, high level and low unemployment and price stability. Macroeconomic indicators - especially inflation, gross domestic product growth, public deficits and unemployment - stand central in economic governance. Policy-makers use them to assess their economies' health (Mügge, 2016).

Intuitively higher government saving rate (measured as the percentage of budget surplus in GDP) is likely to affect economic growth positively through two channels: (1) countries which have higher government saving rates also tend to have greater overall savings and investment, and therefore grow faster; and (2) higher government saving indicates sound overall macroeconomic management, which lowers risks for investors and increases investment leading to a higher rate of economic growth (Ciftcioglu and Begovic, 2008).

Economic growth is characterized by increasing the scale of aggregate production and consumption, defined as a gross domestic product. GDP reflects the market value of all goods and services in all economic sectors for consumption, export and accumulation. Therefore, this indicator is the major macroeconomic indicator that reflects the results of the functioning of the economy (Ableeva, 2014). The objective behind a calculation of GDP per capita is to quantify the average amount of goods and services available to each person in an economy (Angeles, 2008). Real GDP tends to underestimate the increase in real domestic income and welfare when the terms of trade improve (Kohli, 2004).

Forecasters commonly predict real gross domestic product growth from monthly indicators such as industrial production, retail sales and surveys, and therefore require an assessment of the reliability of such tools (Diron, 2008). The government's calculation of real GDP growth begins with the estimation of nominal GDP, which is the market value of the millions of goods and services sold in the market to households, firms, governments, and foreign buyers (Feldstein, 2017).

One of the main goals for most developing countries is to achieve stable and long-term growth and maintain political stability. In order to make it feasible, each country should attract more foreign direct investment, which would contribute to the development of the country in a certain period (Domazet and Marjanović, 2018b).

One of the key economic performances is the unemployment rate. Unemployment reacts simultaneously with the economy as a whole. It decreases and increases in line with the business cycles. Unemployment is seen as a situation in which working-age persons cannot find employment 
with their qualifications. Unemployment occurs on an equal footing in both developed and underdeveloped countries, where the standard of living is low. As Veselinovic (2013) cites the underutilisation of the human potential of a country, it has a direct impact on its national economy and gross domestic product, which, among other things, results in a low standard of living and poverty. In the opinion of Su (2014), the results of the Granger causality analysis show that the unemployment-related search indices can improve predictions of the macroeconomic indicators. It suggests that unemployment-related searches can potentially provide valuable, timely, and low-cost information for macroeconomic monitoring.

\section{RESEARCH METHODOLOGY AND RESULTS}

Since the development of each economy is greatly influenced by an actively driven macroeconomic policy, this paper will seek to present the current state of national economies of Southeast Europe when it comes to certain macroeconomic indicators. The aim is to show the mutual relationship and position of each of the countries observed through a comparative analysis of the selected indicators. The analysis is focused on (a) real GDP and the unemployment rate in the domain of Economic activity, (b) consumer prices and producer prices in the domain of Prices, wages and exchange rates, (c) gross foreign direct investment in the domain of Foreign trade and capital flows, and (d) total government debt in the domain of Government finance. The analysis was performed based on the available secondary data, i.e., data available in Eurostat Databases and the National Statistical Institutes of each of the countries observed. The period covered by the analysis referred to 2018 and the first two quarters of 2019 .

The first part of the analysis was aimed at presenting Real GDP in the selected SEE countries in the observed period. Real gross domestic product (GDP) is a macroeconomic measure of the value of economic output adjusted for price changes (i.e., inflation or deflation), respectively, is an inflation-adjusted measure that reflects the value of all goods and services produced by an economy in a given year, expressed in base-year prices. Based on the results presented in Table 1, it can be seen that in the first two quarters of 2019, Real GDP was in the range of 2.4 (Croatia) to 4.5 (Romania).

According to Kuzmanović (2007), gross domestic product (GDP) represents the total production of goods and services that have been achieved in the national economy over one year, regardless of ownership. 
Also, GDP is defined as the most famous and commonly used macroeconomic aggregate of the National Accounts System.

Table 1. Real GDP (\% change, YoY)

\begin{tabular}{|c|c|c|c|c|c|c|}
\hline & Q1 2018 & Q2 2018 & Q3 2018 & Q4 2018 & Q1 2019 & Q2 2019 \\
\hline BiH & 3.5 & 3.9 & 3.1 & 3.9 & 2.8 & 2.6 \\
\hline Croatia & 2.5 & 2.9 & 2.8 & 2.3 & 3.9 & 2.4 \\
\hline Montenegro & 4.5 & 4.9 & 5.0 & 4.8 & 3.0 & 3.2 \\
\hline North Macedonia & 0.9 & 3.0 & 3.0 & 3.7 & 4.1 & 3.1 \\
\hline Romania & 4.3 & 4.1 & 3.7 & 4.0 & 5.0 & 4.5 \\
\hline Serbia & 4.9 & 4.9 & 4.1 & 3.4 & 2.7 & 2.9 \\
\hline Slovenia & 4.3 & 3.7 & 4.6 & 3.8 & 3.3 & 2.5 \\
\hline
\end{tabular}

Source: Authors based on Eurostat and National Statistical Offices of SEE countries

Table 1 shows the Real GDP (\% change, YoY) for 2018 and the first two quarters of 2019, where it is seen that it varies from country to country. Looking at the second quarter of 2019, and excluding Romania, which has the highest Real GDP (4.5\%), the other analyzed countries are in the range of $2.4 \%$ to $3.2 \%$. In the first semester of 2019, economic growth in Bosnia and Herzegovina slowed slightly, the main reason being the increase in the foreign trade deficit. It is characteristic of Croatia that the economy has been continuously growing for 19 consecutive quarters, and this represented one of the highest growth rates of the GDP for the first quarter of 2019 among the EU member states. The main drivers of growth in 2019 were a large increase in public investments. When it comes to the real GDP growth rate of Montenegro, the positive economic trends which contributed to the significant real GDP growth of $5.1 \%$ in the previous year, continued their positive trend in the first half of 2019. A high amount of uncertainty for the process of the EU accession has led to oscillations in the North Macedonian economy, which was reflected through the growth of the Real GDP, and then there was a decrease in 2019 of $24 \%$, thus reaching 3.1 in Q2. Although the dynamics of real GDP in Romania was positive, with an annual growth of $4.1 \%$ in 2018, the pace of economic growth is slowing down. The overall 
2019 real GDP growth is predicted to reach 4\%. In Serbia, the real GDP growth was $4.4 \%$ in 2018. Through the first two quarters of 2018, the Serbian economy has continued to grow. The last two quarters of the same year resulted in the real GDP drop. That trend continues in the first quarter of 2019, and in 2019 the real GDP is expected to be 3.5\%. Slovenia's economic growth continued to be driven primarily by investment, but export growth also accelerated in the first part of 2019, particularly exports of medicinal and pharmaceutical products.

Table 2 shows the unemployment rate in the observed period for the selected SEE countries. The unemployment rate is the share of the labour force that is jobless, expressed as a percentage. When the economy is in poor shape and jobs are scarce, the unemployment rate can be expected to rise. When the economy is growing at a healthy rate and jobs are relatively plentiful, it can be expected to fall.

Table 2. Unemployment rate (registered, \% pa)

\begin{tabular}{|c|c|c|c|c|c|c|}
\hline & Q1 2018 & Q2 2018 & Q3 2018 & Q4 2018 & Q1 2019 & Q2 2019 \\
\hline BiH & 37.3 & 36.1 & 35.7 & 34.8 & 34.3 & 33.0 \\
\hline Croatia & 12.1 & 9.5 & 8.5 & 9.2 & 9.4 & 7.3 \\
\hline Montenegro & 16.1 & 14.4 & 14.1 & 16.1 & 15.0 & 14.3 \\
\hline North Macedonia & 21.6 & 21.1 & 20.8 & 19.4 & 17.8 & 17.5 \\
\hline Romania & 4.8 & 4.3 & 4.0 & 4.2 & 4.2 & 4.1 \\
\hline Serbia & 14.8 & 11.9 & 11.3 & 12.9 & 12.1 & 10.3 \\
\hline Slovenia & 9.0 & 8.1 & 7.9 & 8.0 & 8.3 & 7.5 \\
\hline
\end{tabular}

Source: Authors based on Eurostat and National Statistical Offices of SEE countries

In the last quarter of 2018 and the first two quarters of 2019, there was a constant increase in the number of employees in Bosnia and Herzegovina in almost all areas. Due to the increase in the number of employees, unemployment has been steadily declining in the mentioned period. In 2018, the lowest survey unemployment rate was registered in $\mathrm{BiH}$ and amounted to $18.4 \%$. In the second quarter of 2019 , the unemployment rate in Croatia 
reached only $7.3 \%$, which is another record low unemployment level in the post-crisis period. The fall of unemployment is partly a result of increased economic growth and new job openings as well as active labour market policies. The number of employed persons in Montenegro in the first six months of 2019 was $8.9 \%$ higher than in the same period last year, while the number of unemployed persons in the first half of 2019 was $17.6 \%$ less than in the same period last year. The highest growth was recorded in the sectors of professional, scientific and technical activities, construction and accommodation services. Gender inequality is one of the challenges of the Macedonian labour market. In the past ten years, the activity rate of women remained significantly lower (44.3\% (women) and 69.3\% (men)). Although the employment rates of women are continuously increasing since 2012, the differences between the genders are deepening because those of men are rising more intensively. In the first half of 2019, in Romania, the number of employees economy-wide descended (annual change of $1.4 \%$ in Q1 and 1.1 $\%$ in April-May, down from 1.6\% in the second half of 2018). From a structural perspective, a disturbing evolution was the deceleration owed to the private sector, amid the slower hiring pace in market services and industry downsizing (especially in the automotive sector). When it comes to Serbia, the employment rate dropped in the last quarter of 2018 and then remain steady in the first quarter of 2019. In the second quarter of 2019 rose by $49.2 \%$. At the end of the second quarter of 2019, unemployment in Serbia was $9.5 \%$. Although the unemployment rate has been significantly reduced, it is still higher than in the developed countries of Europe. In the first six months of 2019, employment in Slovenia continued to rise, albeit at a slower pace than in previous years. A large share of enterprises continues to face a shortage of appropriately skilled workers due to a mismatch between the skills of young people entering the labour market and the skills sought after by employers. Employment growth is expected to slow down in the next period under the impact of weaker growth in economic activity and, increasingly, demographic trends.

Table 3 shows the percentage of change in consumer and producer prices over the observed period for the selected SEE countries. There are two inflationary measures, the Consumer Price Index (CPI) and the Producer Price Index (PPI). CPI is a measure of the total value of goods and services consumers have bought over a specified period, while PPI is a measure of inflation from the perspective of producers (Ülke and Ergun, 2014). 
Table 3. Consumer and producer prices (\% change, yoy, pa)

\begin{tabular}{|c|c|c|c|c|c|c|c|c|}
\hline & & $\begin{array}{l}\text { Bosnia } \\
\text { and } \\
\text { Herze- } \\
\text { govina }\end{array}$ & Croatia & $\begin{array}{l}\text { Monte- } \\
\text { negro }\end{array}$ & $\begin{array}{l}\text { North } \\
\text { Mace- } \\
\text { donia }\end{array}$ & Romania & Serbia & Slovenia \\
\hline Consumer prices & Q1 & 0.8 & 1.0 & 2.7 & 1.5 & 3.73 & 1.6 & 1.3 \\
\hline Producer prices & 2018 & 3.2 & 1.3 & -0.6 & 0.8 & 3.5 & 0.8 & 2.2 \\
\hline Consumer prices & Q2 & 1.4 & 1.9 & 3.2 & 1.5 & 4.53 & 1.8 & 1.9 \\
\hline Producer prices & 2018 & 0.8 & 2.4 & 1.1 & -0.2 & 6.1 & 3.0 & 2.1 \\
\hline Consumer prices & Q3 & 0.9 & 1.9 & 2.7 & 1.6 & 4.56 & 2.4 & 1.9 \\
\hline Producer prices & 2018 & 2.3 & 3.7 & 2.0 & -0.8 & 6.4 & 3.6 & 2.4 \\
\hline Consumer prices & Q4 & 1.7 & 1.3 & 1.8 & 1.2 & 4.3 & 2.0 & 1.9 \\
\hline Producer prices & 2018 & 2.5 & 2.0 & 2.9 & -1.0 & 4.87 & 1.1 & 1.6 \\
\hline Consumer prices & Q1 & 1.0 & 0.5 & 0.5 & 1.2 & 4.1 & 2.4 & 1.3 \\
\hline Producer prices & 2019 & 1.4 & 1.5 & 0.9 & 0.2 & 5.6 & 1.7 & 1.1 \\
\hline Consumer prices & Q2 & 0.6 & 0.7 & 0.5 & 1.2 & 3.9 & 2.3 & 1.6 \\
\hline Producer prices & 2019 & 0.6 & 1.5 & 1.1 & 0.9 & 4.2 & 0.7 & 0.9 \\
\hline
\end{tabular}

Source: Authors based on Eurostat and National Statistical Offices of SEE countries

Inflation measured by the Consumer Price Index in Bosnia and Herzegovina was 1.2\% in 2018. In the first two quarters of 2019, there was a slight fall in the price level, so in the second quarter of 2019 inflation was $0.6 \%$. The highest price increase in the first two quarters of 2019 was in the sections of alcoholic beverages and tobacco $(4.2 \% \mathrm{y} / \mathrm{y}$; influenced by the increase in excise taxes) and transportation $(2.9 \% \mathrm{y} / \mathrm{y})$. In Croatia, the consumer price index (CPI) fell significantly in the first two quarters of 2019 compared to 2018 (to $0.5 \%$ and $0.7 \%$ respectively) as anticipated, thanks to tax measures that came into force from 1st January 2019. Namely, the VAT reductions from $25 \%$ to $13 \%$ on various unprocessed food products (meat, eggs, fresh fruits, and vegetables, etc.) subdued the rise of prices of these products that are a significant part of the consumer basket. The low consumer prices in the Eurozone also contributed to a rather low inflation rate in Croatia in the first half of 2019. The consumer and producer price index saw a stable increase in the observed period in North Macedonia. The largest increase in production prices was recorded in the fourth quarter of 2018, where an increase of $26.6 \%$ is realized since the previous quarter. From there on out, 
the producers' prices fall for a significant percentage of $25 \%$, and remain stable in the last two quarters. On the side of the demand, the biggest increase of the consumer price index in the observational period is noted in the first quarter of 2019, where the index went down 0.9 percentage. Inflation in Romania in 2018 stood at $4.1 \%$, the highest in the EU. Annual consumer price growth remained strong in the first and second quarters of 2019, around 4\%. However, it is expected to decelerate in the third quarter. Inflation evolution synthetically reflects the uncertainty around the perspectives of the economic environment and the construction and implementation of economic policies. In Serbia, consumer prices are higher inter-annually in the two-quarters of 2019, then the lower limit on the targeted inflation of the National Bank of Serbia for the same year. When we analyze the contribution of consumer prices by purpose, we can see that the share of unprocessed food is the biggest, and processed food has the smallest share in the whole contribution of customer price growth. In June 2019, consumer prices in Slovenia grew on average by $1.8 \%$ at the annual level. In the first half of 2019, inflation was primarily driven by domestic factors. In addition to favourable economic conditions and rising household consumption, inflation continues to be driven mainly by higher prices of services.

Table 4 shows gross foreign direct investment over the observed period for the selected SEE countries. Foreign direct investments are considered to be an effective means to raise comparative advantages of one country, where it requires the internationalization of business, in which the main actors are multinational companies (Domazet \& Marjanović, 2018a).

Table 4. Gross foreign direct investment (EUR million)

\begin{tabular}{|c|c|c|c|c|c|c|}
\hline & Q1 2018 & Q2 2018 & Q3 2018 & Q4 2018 & Q1 2019 & Q2 2019 \\
\hline BiH & 144 & 72 & 124 & 59 & 129 & 203 \\
\hline Croatia & 533 & 496 & 90 & -157 & 343 & -28 \\
\hline Montenegro & 138.38 & 265.24 & 184.58 & 269.92 & 181.76 & 193.0 \\
\hline North Macedonia & 294.2 & 126.4 & 41.2 & 77 & 220.3 & 118.7 \\
\hline Romania & 850.49 & 601.02 & 909.35 & 282.95 & 444.82 & 313.86 \\
\hline Serbia & 723.5 & 682.1 & 598.1 & $1,184.2$ & 800.5 & 994.9 \\
\hline Slovenia & 284 & 216 & 483 & 311 & 847 & 44 \\
\hline
\end{tabular}

Source: Authors based on Eurostat and National Statistical Offices of SEE countries 
In the first half of 2019, gross foreign direct investment in Bosnia and Herzegovina stood at EUR 332 million, a 53\% increase compared with the same period last year. However, in addition to significant shifts, relatively favourable business and investment climate have not been created and an institutional environment built to attract foreign investors, which is one of the key constraints on economic development and growth in the coming period. The significant growth of investments in Croatia will be pronounced in 2019 (8\%) owing to the large infrastructure projects. The main sources of growth are attributed to the increase in gross investment in fixed assets and domestic consumption, albeit at a much slower pace than in the previous quarter. In the first two quarters of 2019, the net inflow of foreign direct investment in Montenegro is $48 \%$ more than in the same period of the previous year, as a result of an increase in inflows from equity investments and a decrease in the total outflow. When it comes to North Macedonia, the financial account of the balance of payments in 2018 recorded significant net inflows, mainly in the form of foreign direct investments, as well as borrowing on the international financial markets. Due to the reduced external borrowing of the economy and offsetting the positive effects of FDI inflows with net outflows on some of the short-term financial flows, in 2019, the deficit had to be financed mainly by foreign reserves, which led to their reduction. The FDI-to-GDP ratio in Romania rose above $2 \%$ and covered an important fraction of the trade deficit. In the first seven months of 2019, the number of newly established foreign capital companies increased, with 3,348 new companies having a share capital totalling 13.59 million US dollars, a 37.4 increase over the January-July 2018 period. The growth of foreign direct investment in Serbia is the result of two main factors. The first is to strengthen the European economy, which has boosted investor confidence and triggered the investment expansion, especially in manufacturing. Another reason is the efforts made to attract FDI through promotional activities, reform of the commercial environment, and investment packages tailored for large foreign companies. Serbia, which has the highest inflow of foreign direct investment in the region, saw a 44 percent growth in 2018. In the first six months of 2019, FDI inflows amounted to approximately EUR 1.8 billion. Over the last five years, there has been a growing trend of FDI, which contributes to the fact that the net inflow of these investments is more than sufficient to cover the current account deficit. FDI inflow strengthened further in Slovenia, including via privatization and takeovers in the insurance and non-financial activities. Slovenian outward FDI was on a significantly lower level. Year on year (YoY) growth in investment has 
strengthened slightly from the end of 2018. Gross fixed capital formation increased by $10.0 \%$ and $6.9 \%$ YoY in the first two quarters of 2019.

Table 5 shows the total government debt over the observed period for the selected SEE countries. Government debt can be categorized as internal debt (owed to lenders within the country) and external debt (owed to foreign lenders). Less creditworthy countries sometimes borrow directly from a supranational organization (e.g. the World Bank) or international financial institutions.

Table 5. Total government debt (eop. \% of GDP)

\begin{tabular}{|c|c|c|c|c|c|c|}
\hline & Q1 2018 & Q2 2018 & Q3 2018 & Q4 2018 & Q1 2019 & Q2 2019 \\
\hline BiH & 26 & 25 & 25 & 24.5 & 25.4 & 23.4 \\
\hline Croatia & 80.5 & 75.8 & 75.4 & 74.1 & 75.4 & 75.5 \\
\hline Montenegro & 57.1 & 66.5 & 66.3 & 67.6 & 66.2 & 65.2 \\
\hline North Macedonia & 39.8 & 40.1 & 40.1 & 40.5 & 38.2 & 38.4 \\
\hline Romania & 34.5 & 34.3 & 34.2 & 35.0 & 34.1 & 34.2 \\
\hline Serbia & 56.3 & 56.8 & 56.8 & 54.5 & 50.9 & 51.4 \\
\hline Slovenia & 75.6 & 72.9 & 71.4 & 70.4 & 68.1 & 67.7 \\
\hline
\end{tabular}

Source: Authors based on Eurostat and National Statistical Offices of SEE countries

In Bosnia and Herzegovina, the budget surplus trend continued in 2019 (KM 726 million in the first semester of 2019). A positive trend in government finance has contributed to the reduction of domestic government debt, which has been reduced by $8 \%$ over a period of one year. The total government debt in 2019 was just over $25 \%$. The level of total public debt in Croatia slightly increased in the course of 2019 reaching $75.4 \%$ in the first quarter, mainly due to the new government bonds issued. In May 2019 the total government debt amounted to HRK 286.8bn, which is up by HRK 2.1 billion, compared to the level at the end of 2018. In Montenegro, the total government debt (without deposits) at the end of June 2019 amounted to $65.2 \%$ of GDP. External debt was $54.6 \%$ of GDP, domestic debt was $10.66 \%$ of GDP, net government debt at the end of June 2019 amounted 
to $61.4 \%$ of GDP. The majority of sovereign debt is serviced at fixed interest rates $(74.9 \%)$ so that the interest rate structure of sovereign debt can be assessed as favourable. The total public government debt has increased at the amount above 5.4 billion euros, but relatively, as the percentage of GDP in Q2 of 2019 declined by $0.2 \%$. Improving the efficiency and equity of public spending as well as strengthening revenue mobilization remain priorities for fiscal policy to reduce the high debt levels, create fiscal buffers to mitigate risks and improve the delivery of public services in North Macedonia. Romania's government debt in accordance with the EU methodology was at 35\% of GDP at the end of 2018, which is much lower than the ceiling of $60 \%$ set by the Maastricht Treaty. The Government informed the European Commission that it projects end-2019 public debt at RON 362.6 billion, some 10\% up from one year earlier. Such a rise accounted for around $1 \%$ of the GDP. Serbia has an almost stable external foreign debt trend from 2017 until the second quarter of 2019. The average percentage change in that period was approx $1 \%$. The decline in public debt has continued, and most likely, by the end of 2019 debt to GDP will be around $50 \%$. Good fiscal prospects reflected on the level of interest rates on government debt. In Slovenia, the debt-to-GDP ratio decreased further in 2018. Supported by economic growth and active public debt management, it stood at $70.1 \%$ and was 4.0 percentage points down compared to 2017.

\section{CONCLUSION}

One of the main goals for each national economy and, therefore, economic policymakers is to maintain a general macroeconomic balance. This objective is achievable if trends in macroeconomic indicators are viewed quantitatively and qualitatively, with a timely response to their movements. However, the choice of macroeconomic instruments is not the same for each country. Unlike developed countries, which rely on fewer instruments such as fiscal and monetary policy, other countries, in addition to mandatory fiscal policy (public spending and taxes) and monetary policy (money supply and interest rate), must be guided by income sharing and exchange policies with foreign countries. If one policy is not properly managed, it can have consequences in the form of restrictions on the other policy, all of which may adversely affect the country's macroeconomic situation. Therefore, the goal of macroeconomic policy is to provide sustainable economic stability in the country and thus prepare the conditions for economic growth. 
As one of the major macroeconomic aggregates, GDP is suitable for analyzing the state of the economy of a particular country. Macroeconomic and financial stability, better investment and business environment, as well as the realization of infrastructure projects are factors that can contribute to investment growth.

One of the key issues for each country is the percentage of employment in the working-age population. In addition to the level of gross domestic product, this is certainly the most consistent indicator of the efficiency of an economy. Faster employment growth than GDP growth reflects a fall in labour productivity and rising labour costs. This scenario reflects a decrease in the competitiveness of a country's economy.

Real GDP in Serbia in the first two quarters of 2019 was about 2.8, while in other countries, it ranged from 3.1 to 4.8 (except for $\mathrm{BiH}$, which has 2.7). The real GDP growth in 2018 compared to the previous year was $4.4 \%$, while in the second quarter of 2019, it was 2.9 percent over the same period last year. By activity, in the second quarter of this year, compared to the same period of 2018, the most significant real growth of gross value added was recorded in the construction sector (16.8 percent) and information and communication (8.2 percent). Given that the unemployment rate in $\mathrm{BiH}$ is 33.6, in North Macedonia 17.6 and Montenegro 14.6, in Serbia it stands at 11.2 but still lags behind Romania (4.1). Compared to the second quarter of 2018, the number of unemployed in Serbia has been reduced partly due to higher employment and partly due to a decrease in the labor force contingent. Further effort is needed in the coming period to bring this rate closer to the EU average. Serbia attracted a significantly higher amount of FDI relative to the countries observed. If activities that contribute to a favorable investment climate continue, it can be expected that in 2020 it will be the leader in the region when it comes to FDI inflows. According to the results presented, the total government debt in Serbia is just above $50 \%$ of GDP, and the country is no longer threatened by the imminent threat of a public debt crisis.

The monetary policy goals in 2020 in SEE countries will continue to be focused on price stability and stable exchange rate, continuous stability of the financial system, supporting macroeconomic stability, and deepening of the financial intermediation level. 
- Security Challenges and the Place of the Balkans and Serbia in a Changing World -

\section{REFERENCES}

Ableeva A.M. (2014). Trend studies of macroeconomic indicators in comparable prices. International Journal of experimental education, 6, pp. 57-58.

Angeles, L. (2008). GDP per capita or real wages? Making sense of conflicting views on pre-industrial Europe. Explorations in Economic History, 45(2), pp. 147-163. doi.org/10.1016/j.eeh.2007.09.002

Ciftcioglu, S. \& Begovic, N. (2008). The relationship between economic growth and selected macroeconomic indicators in a group of Central and East European countries: a panel data approach. Problems and Perspectives in Management, 6(3), pp. 24-30.

Diron, M. (2008). Short-term forecasts of euro area real GDP growth: an assessment of real $\square$ time performance based on vintage data. Journal of forecasting, 27(5), pp. 371-390. doi.org/10.1002/for.1067

Domazet, I. \& Marjanović, D. (2018a). FDI as a Factor of Improving the Competitiveness of Developing Countries: FDI and Competitiveness, in: V. Malepati (Ed.), Foreign Direct Investments (FDIs) and Opportunities for Developing Economies in the World Market (pp. 82-104). Hershey, IGI Global.

Domazet, I. \& Marjanović, D. (2018b). Foreign Direct Investment and Economic Development: Comparative Analysis of Bulgarian, Romanian and Serbian Economies, in: Western Balkans Economies in EU Integration: past, present and future (pp. 150-171). Nice, CEMAFI International Association.

Feldstein, M. (2017). Underestimating the Real Growth of GDP, Personal Income, and Productivity. Journal of Economic Perspectives, 31(2), pp. 145164. doi: $10.1257 /$ jep.31.2.145

Josifidis, K. (2010). Makroekonomija - principi, teorije, politike [Macroeconomics - Principles, Theories, Politics]. Novi Sad, Futura.

Kohli, U. (2004). Real GDP, real domestic income, and terms-of-trade changes. Journal of International Economics, 62(1), pp. 83-106. doi.org/10.1016/j.jinteco.2003.07.002

Kuzmanović, Đ. T. (2007). Nacionalna ekonomija [National Economics]. Novi Sad, Alfa - Graf NS.

Mügge, D. (2016). Studying macroeconomic indicators as powerful ideas. Journal of European Public Policy, 23(3), pp. 410-427. doi.org/10.1080/13501763. 2015.1115537 
Petrović, J., Jovanović, M., \& Mandžukić, Lj. (2013). Ostvarivanje makroekonomskih ciljeva u novoj ekonomiji [Achieving Macroeconomic Goals in the New Economy]. Ekonomika [Economics], 2, pp. 191-199.

Sédillot, F. \& Pain, N. (2003). Indicator Models of Real GDP Growth in Selected OECD Countries, retrieved from https://www.oecd-ilibrary. org/docserver $/ 275257320252$.pdf?expires $=1580753067 \&$ id=id\&accnam $\mathrm{e}=$ guest\&checksum=C05FC469384F06E127CF4F89300D4EDD. Accessed 18 December 2019.

$\mathrm{Su}, \mathrm{Z}$. (2014). Chinese Online Unemployment-Related Searches and Macroeconomic Indicators. Frontiers of Economics in China, 9(4), pp. 573-605.

Tas, N., Hepsen, A. \& Önder, E. (2013). Analyzing Macroeconomic Indicators of Economic Growth using Panel Data. Journal of Finance and Investment Analysis, 2(3), pp. 41-53. doi.org/10.2139/ssrn.2264388

Ülke, V., \& Ergun, U. (2014). The Relationship between Consumer Price and Producer Price Indices in Turkey. International Journal of Academic Research in Economics and Management Sciences, 3(1), pp. 205-222. 